In Ireland of 26 corpses examined, 21 contained organo-chlorine residues, mainly dieldrin - they included a foxhound, eleven pheasants, a kestrel, two thrushes, three pigeons, a bullfinch, four salmon and three trout, and in each case death was attributed to the poisoning. In addition, duck, peregrine and sea bird eggs showed traces of several organochlorine insecticides, including dieldrin, lindane, aldrin and DDT.

In Scotland everywhere except on Deeside golden eagles are raising very few young, although there has been no obvious decline in the number of adults. This is believed to be the result of toxic insecticides, residues of which have been found in both birds

Effect of

Poisons on

Colden Eagles and eggs. The reason for Deeside being unaffected, suggests Adam Watson in the 1966 report of the Grouse and Moorland Ecology Unit, is that they feed mostly on grouse and hardly ever eat dead sheep, as eagles in the west of Scotland do, thus getting the insecticides from the sheep dips.

\title{
The Revolving Fund
}

\section{ELEPHANTS IN CEYLON, LEMURS IN MADAGASCAR, CRESTED IBIS IN JAPAN}

\begin{abstract}
$A^{T}$ its meeting on January 3 Council agreed the following grants $A$ from the Revolving Fund: $£ 1750$ towards the Ceylon elephant survey, and $£ 1000$ each towards the projects to save the endangered fauna of Madagascar and the Japanese crested ibis. All three are World Wildlife Fund projects, certified by the International Union for Conservation of Nature as scientifically valid, and given the highest priority by the World Wildlife Fund Trustees. The grant to the Ceylon Wild Life Society is for the purchase of two land rovers for the Ceylon National Parks, which will be made available to the team of American scientists who are making an ecological survey of the Ceylon elephant. Fewer than 1500 elephants remain in Ceylon, and numbers are rapidly diminishing as the habitat available to them steadily shrinks.

The unique fauna of Madagascar is the most seriously threatened of any of the world's specialised local faunas, the aye-aye, for instance, being down to something of the order of a dozen individuals. Here again the main danger is steady and continuous destruction of habitat. The grant goes towards enabling Dr. J-J. Petter, the leading expert on the Madagascan fauna and its conservation, to embark on a general conservation programme for this gravely endangered fauna. A note on the successful start that he has already made is on page 3 .
\end{abstract}

The Japanese crested ibis is the rarest bird species in the world 
whose numbers are certainly known-at the last count there were only 12 in existence. The grant will go to help the considerable efforts that are being made in Japan to preserve both the breeding and the feeding areas of the species.

Altogether 277 mammals and 321 birds are in danger of extinction at this moment. The Revolving Fund can only make a very small nibble at the immense task that this represents, but it can do something, and in its first year it has made a considerable impression. A number of FPS members have sent generous donations; may we urge others to do the same?

The Revolving Fund has been set up to help save urgent casesquickly. Time is very often the most important ingredient for success. Please help.

\section{FPS TOURS TO INDIA AND KENYA}

THE first FPS tour to India takes place in February, 1968, as already announced. The tour, whose guides will include $\mathrm{Mr}$. Zafar Futehally, hon. secretary of the Bombay Natural History Society, and Mr. E. P. Gee, member of the India Wild Life Board and well known to FPS members as an authority on Indian wildlife, will visit among other places the Gir Forest (for the Indian lion), the Kanha (tigers) and the Corbett National Parks, the famous Kaziranga sanctuary for the great Indian rhino in Assam and the Manas sanctuary close to the Himalayas where the rare golden langur monkey is found, as well as Bombay, New Delhi, Agra and the Taj Mahal.

The third tour to East Africa, also in February, 1968, will be in Kenya with the emphasis on birds-as many as 500 different species may well be seen in addition to all the usual large game animalslions, elephants, giraffes, antelopes, etc. Lakes Naivasha and Nakuru, Mount Kenya and the Aberdares, Samburu, the Tsavo, Treetops and the coast will all be visited.

A few places are still available on both tours. For details please write to Miss Elizabeth Giles, FPS Administrative Secretary.

\section{Oil Pollution of the Sea}

The good news announced at the Cambridge conference of the International Council for Bird Preservation last July, that the 1962 amendments to the Convention for the Prevention of Pollution of the Sea by Oil would come into force in May this year, has been tragically overshadowed by the disaster of the Torrey Canyon. But the amendments are important. They bring a much larger number and variety of ships within the provisions of the Convention, including naval vessels and tankers as small as 150 tons, prohibit the discharge of oil into the sea by ships of over 20,000 tons, and considerably enlarge the zones in which oil may not be discharged at all. 